\title{
Oil Recovery of Soil Contained Petroleum Oil by Using Bio Surfactant of Mixed Cultures Bacteria (Brevundumonas diminuta, Pseudomonas fluorescens, Pseudomonas aeroginosa, Pseudomonas citronelis) at vary $\mathrm{pH}$ Conditions (5-9)
}

\author{
Bambang Yudono ${ }^{\#}$, Fatma ${ }^{\#}$, Sri Pertiwi Estuningsih", Lilis Suganda ${ }^{\#}$ \\ "Department of Chemistry, Faculty of Mathematics and Sciences, University of Sriwijaya, Palembang 30139, Indonesia \\ Email:yudonob@hotmail.com, fatmakamal62@gmail.com, lilissuganda128@gmail.com \\ "Department of Biology, Faculty of Mathematics and Sciences, University of Sriwijaya, Palembang 30139, Indonesia \\ Email: ${ }^{3}$ spertiwie@gmail.com
}

\begin{abstract}
The bacteria (Brevundumonas diminuta, Pseudomonas fluorescens, Pseudomonas aeroginosa, Pseudomonas citronelbis) which are indigenous bacteria from Babat Toman village South Sumatra. It was isolated and identified by using Bergey's method. In the normal condition ( $\mathrm{pH} 7$ ), these bacteria could produce bio surfactant and effectively as a mixed culture. The growth of a mixed culture of indigenous bacteria was tested at different $\mathrm{pH}$ conditions (5-9). The results show that the optimum $\mathrm{pH}$ was obtained at $\mathrm{pH}$ 7, the population of bacteria was $2.14 .10^{7} \mathrm{cfu} / \mathrm{mL}$. The shortest regeneration time of these bacteria were $(12,12,9,9)$ hours respectively. The initial total petroleum hydrocarbon concentration of the sample was $18,4 \%$, it was extracted by using the bio surfactant of mixed culture with $10 \%$ concentration at different $\mathrm{pH}$ conditions (5-9), the contact time as long as 168 hours. The optimal oil recovery was obtained at $\mathrm{pH} 7$ as much as $20.97 \%$. It can be concluded that the bio surfactant effectively used in the normal condition (pH 7 ) and ineffectively in alkaline condition (pH 9). The GC analyses were conducted to initial crude oil and the residue. The results show that the crude oil consists of 33 components and the residue consists of 14 components. It shows that the bio surfactant of mixed culture bacteria dissolved the hydrocarbon components with temperature fractions 150, 155, 178, 184, 190, and $197^{\circ} \mathrm{C}$.
\end{abstract}

Keywords — bio surfactant; petroleum; oil recovery

\section{INTRODUCTION}

Biosurfactants are surface-active compounds synthesized by microbes [1], [2]. This compound consists of a hydrophobic and a hydrophilic group and has the ability to lower the surface tension of a liquid and the interfacial tension between two different phases, and increased emulsion stability [3], [4], [5], [6]-[7]. Biosurfactants have several advantages over synthetic surfactants, among others, the level of low toxicity, high biodegradability, and has a high activity at a temperature, $\mathrm{pH}$ and salinity extremes. and low production costs. Additionally, biosurfactant can be synthesized from renewable raw materials. [2], [8]. Biosurfactant application in the petroleum field includes environmental bioremediation of contaminated oil, crude oil drilling, and enhanced oil recovery (EOR), pharmacy, medical, cosmetics, food and pharmaceutical [9], [10]-[11]. Thus among all Oil industry is the greatest market of these compounds [12]. Biosurfactant major role in bioremediation is to trigger the bioavailability of pollutants that can be used by microbes involved in biodegradation processes [13], [14]. Oil pollution in the environment has become a threat to ecosystems and humans through the introduction of toxic organic material including polycyclic aromatic hydrocarbons (HAP) to the environment. [15], [16]. Many bacteria can produce biosurfactant which enables them to degrade or transform insoluble organic compounds such as petroleum products. Therefore, the area contaminated petroleum and industrial waste as a potential source of biosurfactantproducing bacteria and degrade hydrocarbons.

Production of oil contained in the oil wells of untapped overall. Conventional methods can only produce oil about $30-40 \%$ of the total oil content [17]. Therefore, use one of 
the alternative technologies for enhanced oil recovery or remaining trapped in the reservoir is by using microbial methods Enhanced Oil Recovery (MEOR) which is a modification of the Enhanced Oil Recovery (EOR).

MEOR technology works by utilizing microbial processes dominated by bacteria in the reservoir. The bacteria contained in the water wells in the reservoir has a variety of soluble chemical compounds that could be nutrients for bacteria. With the capability of biochemistry, bacteria are so small can be used to remove oil trapped in rocks reservoir, where the basic principle is the use of MEOR secondary metabolites of microbial products to help improve the recovery of oil left, or are still trapped in the reservoir [17].

Decomposition of bacteria by MEOR may include organic and inorganic acids, gas, and water and bio surfactant. Bio surfactants are one bio product produced microbial and very important role in the recovery of oil because of the presence of bio product can reduce the surface tension (interfacial tension) between the two-phase fluid, so that increase the mobilization of the oil [18].

The type of growth substrate, the type of bacteria, the source of nutrients and environmental are factors of major concern to the researchers in the bio surfactant production optimization efforts [19]. The level of acidity $(\mathrm{pH})$ is an important environmental factor for the growth and development of bacteria. If the $\mathrm{pH}$ of the environment is not in accordance with the enzyme activity of microbes, the bacteria cannot properly metabolize. Hence it does not grow optimally [20].

Therefore, it is necessary to test against one of the factors that affect bio surfactant that the environmental effects of $\mathrm{pH}$ (5.0 to 9.0) on the growth of mixed cultures of four strains of bacteria that are Brevundumonas diminuta, Pseudomonas fluorescens, Pseudomonas aerogirosa, and Pseudomonas citronelbis. Four types of bacteria are isolated from the village of Babat Toman South Sumatra and have proven potential as MEOR [21]. This study aims to get the isolates indigenous bacteria producing bio surfactant and degrading hydrocarbons compounds from the environment polluted waste oil in the village Babat Toman South Sumatra.

\section{MATERIAL AND Method/AlgORITHM}

\section{A. Isolate Bacteria}

Four bio surfactant producing bacteria were isolated from 8 different areas of oil contaminated soils, extracted oil reservoirs, oil pipeline leakages and oil sewage and sludge dumps in Babat Toman Village, Banyuasin District of South Sumatera.

\section{B. Equipment Sterilization}

All heat-resistant equipment is sterilized by autoclave at a temperature of $121^{\circ} \mathrm{C}$, while the other equipment is sterilized with $70 \%$ alcohol.

\section{Cultivation Media}

Cultivation media were synthesized in the laboratory by Banat method [22], [23] for microorganism enrichment and Robert method [24], [2] for bio surfactant production.

\section{Bacteria Cultivation}

Sources of bacterial isolates were cultured in enrichment medium and incubated on a shaker speed of $200 \mathrm{rpm}$ for 21 days at a temperature of $30{ }^{\circ} \mathrm{C}$. [25], [26], [27], [28]. The bacterial cultures were diluted into $10^{-3}$. It is taken $1 \mathrm{ml}$ each serial dilution of the tube inserted in a petri dish containing $15 \mathrm{ml}$ of the sterile medium made with a method NA pour plate was incubated for $48 \mathrm{~h}$ at $30{ }^{\circ} \mathrm{C}$. Further purification is done by the method isolates the cup scratch. Isolates on agar plates. Isolates that grow one kind is a pure isolate. Isolates purely made stocks for further study of bio surfactant producing strains [29].

\section{E. Isolation and Purification}

BHMS samples in a liquid medium that have been transformed into a murky diluted started $10^{-1}$ to $10^{-6}$ by way of homogenizing $1 \mathrm{ml}$ sample in a liquid medium BHMS with $9 \mathrm{ml}$ physiological saline dilution diluted $10^{-1}$ to $10^{-6}$. Then from each dilution $10^{-4}, 10^{-5}, 10^{-6}$ Zobell medium grown on agar pour plate method and incubation at room temperature for 2 x 24 hours, then observed bacterial colonies growing. Each dilution of each sample plate Zobell observed colonies grown with different characteristics, based on the differences in morphology (such as color, shape and surface colonies). Colonies that grew up with different characteristics are purified by at Zobell streak in order sterile medium in a petri dish and incubated for $2 \times 24$ hours at $37{ }^{\circ} \mathrm{C}$. This technique is repeatedly done to obtain pure colonies indicated. For pure suspected colonies, gram staining is done to ensure that the colony is indeed pure and consists of only one kind of bacteria only. If it has not obtained a pure colony, repeat it, to obtain pure colonies [29].

\section{F. Characterization and Identification}

Bacterial isolates were tested could produce bio surfactant, further works are characterization and identification. Characterization is done to: colony morphology on a variety of media in order (oblique, upright, and plate), cell morphology (characteristics gram of bacteria and stain endospores), testing biochemical (fermentation of sugars, hydrolyzed starch, hydrolyzed gelatin, test indole, test methyl red, test Voges-Proskauer, test citrate, test $\mathrm{H}_{2} \mathrm{~S}$, hydrolysis test urea, catalase test, and test motility. Based on the character of each of the bacterial isolates capable of degrading hydrocarbons are identified using Bergey's Manual of Determinative Bacteriology 8th edition and Bergey's Manual of Determinative Bacteriology 9th edition [30]

\section{G. Calculation of Shortest Regeneration Time}

Data on the number of cells isolated from each of the observations made in the form of graphs, so that the known phases of growth. The growth curve of the bacterial isolates obtained determined the shortest generation time and the exponential growth phase [31]. The shortest generation time is used as a base for the production of starter bacteria for bio surfactant. The equation used to determine the time of regeneration as follows:

$$
g=\frac{\log 2(t)}{(\log X t-\log X o)}
$$

where: 
$\mathrm{g}=$ regeneration time (regenerations / hour)

$\mathrm{Xt}=$ number of bacterial cells at the end of time (cells / $\mathrm{mL}$ )

$\mathrm{Xo}=$ the number of bacterial cells at initial time points (cells $/ \mathrm{mL}$ )

$\mathrm{t}=$ incubation time of $\mathrm{Xo}-\mathrm{Xt}(\mathrm{h})$

After calculation of the obtained results that the shortest regeneration time for bacteria is 12 hours Brevundumonas diminuta, Pseudomonas fluorescence is 9 hours, for Pseudomonas aerogirosa is 12 hours and the bacteria Pseudomonas citronelis 9 hours [32].

\section{H. Calculation of Number of Cells Affected by $\mathrm{pH}$}

The calculation of the number of cells mixed culture of bacteria with the effect of $\mathrm{pH} 5-9$, carried out in a way taken $10 \mathrm{~mL}$ starter was added to the test tube and added a solution of phosphate buffer $\mathrm{pH} 5,6,7,8$, and 9 then homogeneous into vortex, then grown by incubation at $37^{\circ} \mathrm{C}$ for 12 hours, in which time appropriate longest generation time of bacterial strains used the mixed cultures. Results of incubation at room temperature and place it within the first drops of the mixture is taken and placed in a counting chamber. Observed and counted under a microscope the number of germ cells. Bacterial inoculum used was inoculum with bacterial cell density $\pm 10^{7}$ cells / $\mathrm{mL}$ [21]

\section{Oil Extraction by Using Bio Surfactants}

To produce bio surfactant of $\mathrm{pH}$ each then performed three repetitions so that the results are more accurate, making that is of 3 pieces Erlenmeyer $250 \mathrm{ml}$ containing 100 $\mathrm{ml}$ of medium Zobell liquid, and $10 \mathrm{~mL}$ molasses as a source of carbon sterilized by autoclaved 1 hour the temperature of $121^{\circ} \mathrm{C}$, then the Erlenmeyer subsequently cooled and added to $20 \mathrm{ml}$ of starter culture mix of bacteria that have been made along with $6 \mathrm{ml}$ desired $\mathrm{pH}$ between $\mathrm{pH}$ 5-9. Then add another Zobell liquid medium that has been provided to mix up the volume to $200 \mathrm{ml}$. A total of $200 \mathrm{ml}$ of a mixture incubated for 12 hours. The mixture has been incubated added 10 grams of soil from the homogeneous soil with sludge in the making before, and in the aerator for 7 days then filtered using a filter paper, the precipitate is dried at a temperature of $110^{\circ} \mathrm{C}$.

\section{J. Measurement \% Oil Recovery}

Measurement \% Recovery of oil that is using the formula

$$
\% \text { Oil recovery }=\frac{\left(\% T P H_{\text {initial }} \%{ }^{-} T P H_{\text {final }}\right)}{\% T P H_{\text {initial }}} \times 100 \%
$$

Where:

$\% \mathrm{TPH}$ initial $=\%$ Initial TPH soil contained oil

$\% \mathrm{TPH}$ final $=\% \mathrm{TPH}$ after the addition bio surfactant of $\mathrm{pH}(5-9)$

\section{K. Gas Chromatography Analysis}

Extract of soil contained oil $18.64 \%$ TPH (TPH initial condition) was diluted with n-hexane at a ratio of 1: 9. The results of such dilution are injected into the GC apparatus with an injector temperature of $290^{\circ} \mathrm{C}$. Sample $2.5 \mu \mathrm{L}$ was injected at $40^{\circ} \mathrm{C}$ on hold for 5 minutes; then the temperature is increased $5^{\circ} \mathrm{C}$ in every minute up to $50^{\circ} \mathrm{C}$, then the temperature was increased $10^{\circ} \mathrm{C}$ in every minute up to $280^{\circ} \mathrm{C}$ and holds for 5 minutes. The mobile phase used is Helium.

Samples through each bacteria treatment by $\mathrm{pH}$ variations (5-9), the sample was diluted with n-hexane at a ratio of 1: 9.
The sample is injected into the GC apparatus with GC operation conditions such as the TPH initial condition.

\section{RESULTS AND DISCUSSION}

Bacteria used for bio surfactant are Brevundumonas diminuta, Pseudomonas fluorescens, Pseudomonas aeroginosa, and pseudomonas citronelbis, which are indigenous bacteria isolated from the village Babat Toman South Sumatra, the bacteria isolated and identified by using methods of barge's manual of determinative bacteriology. Furthermore, the bacteria are kept in the incubator as a stock culture. Any bacteria that will be applied, it should be regenerated before being used in the production of bio surfactant. The regeneration of bacteria was performed to obtain the bacteria are active, due to a bacterium that had previously been in an incubator are in the inactive state. Conditions inactivated bacteria become less active when it is used in the production of bio surfactant.

Media used in the regeneration of the bacteria is the NA media (Nutrient Agar), wherein this medium contains nutrients that can support the growth of bacteria. For Nutrient media used in the regeneration of the bacteria because Nutrient Agar is commonly used in heterotrophic microorganisms in solid form. Nutrient to be in solid form can be used in a compactor because it is easily frozen and carbohydrates in the form galactose that is not easily broken down by microorganisms. Similarly, in the previous study [37] which uses the medium nutrient so as regeneration of bacteria in bio surfactant production by the bacteria Pseudomonas aeruginosa.

The components of nutrients available in NA media are yeast extract, peptone, and agar. Yeast extract is one component that contains carbohydrates, nitrogen, vitamins. Peptone is a major source of nitrogen. As a material compactor, the NA media used to be, but here is not a nutrient for bacterial growth [32]. The image of bacteria before and after regenerated as follows:

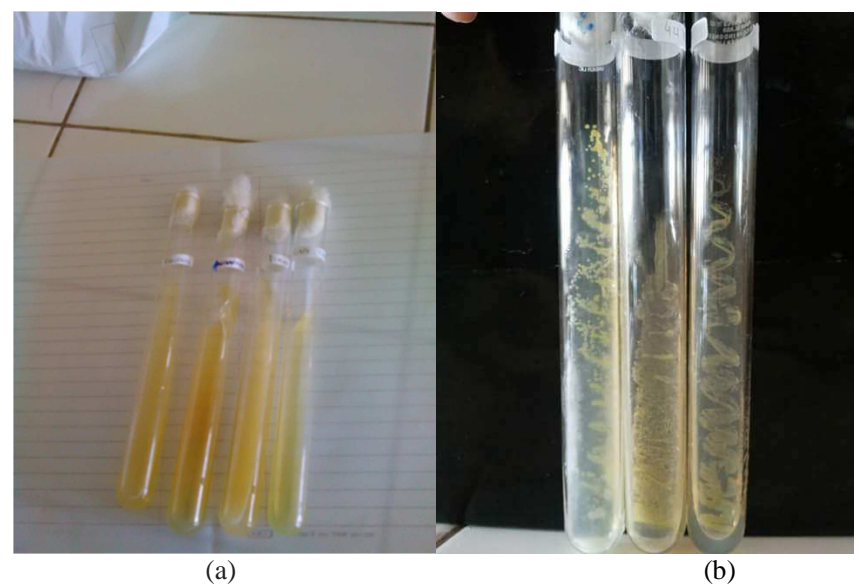

Fig. 1 Bacterial isolates Brevundumonas diminuta, Pseudomonas fluorescens, Pseudomonas aerogirosa, Pseudomonas citronelbis. (a) prior to the regenerated (b) after the regenerated

Based on Fig. 1, the results show that the regeneration of the bacteria the color of bacteria after regenerated younger or fresher than before regenerated, bacteria are visible in the image (b) is the result of the regeneration of the two ose bacterium parent (a) resulting culture single stock of each 
type of bacteria. This indicates that the bacteria have been active and ready for use in the next process in the production of bio surfactant.

The growth curve of bacteria is used to determine the bacterial life cycle. The growth curve of bacteria in this study made to determine the logarithmic or exponential phase of: Brevundumonas diminuta, Pseudomonas fluorescens, Pseudomonas aerogirosa, and Pseudomonas citronelis. In this phase of rapidly dividing bacteria can be doubled at a certain incubation period, so that the number of cells will also be more and more and can be used in the production of bio surfactant [33].

Exponential phase is an important phase in the bio surfactant for enzymes for the production of bio surfactant will be produced during the exponential growth phase [34]. Therefore, in this study need to know the time to achieve exponential phase for the four types of bacteria. The growth curve of types of bacteria can be seen as follows:

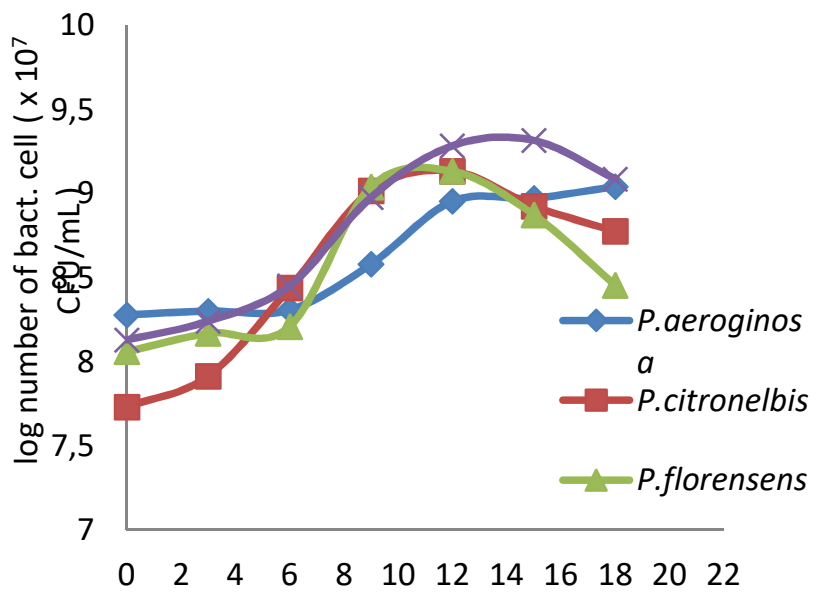

Time (hour)

Fig. 2 The growth curve of bacteria

Based on Fig. 2 shows that the bacterial counts ranging from $10^{7} \mathrm{CFU} / \mathrm{mL}$ with a range of time spent between $0-18$ hours at intervals of every 3 hours once observed, these bacteria produced more than the previous study [35] that produces $10^{6} \mathrm{CFU} / \mathrm{mL}$ of bacteria used was pseudomonas aeroginosa, medium grown culture in this study is a liquid in the medium zobell, while the previous research [35] using a nutrient medium borth it does show that nutrients can affect the growth of bacteria.

The growth curve of the log number of bacterial cells with time can be used within the shortest generation of the respective bacteria. The shortest generation time is the time required by microorganisms to increase the number of cells to double the original amount or the exponential phase. So the exponential phase can be determined using the shortest regeneration time. According to the calculation formula of research [32], the shortest regeneration time data obtained from the four types of bacteria proficiency level are as follows:
TABLE I

DATA IN THE SHORTEST REGENERATION TIME

\begin{tabular}{|l|c|}
\hline \multicolumn{1}{|c|}{ Bacteria } & Shortest Regeneration time (h) \\
\hline Brevundumonas diminuta & 12 \\
\hline Pseudomonas fluorescens & 9 \\
\hline Pseudomonas aerogirosa & 12 \\
\hline Pseudomona citronelbis & 9 \\
\hline
\end{tabular}

Based on Table 1 shows that a regeneration time of the shortest in bacteria Pseudomonas diminuta and Brevundumonas aerogirosa have the same time is 12 hours, while the Pseudomonas citronelbis and Pseudomonas fluorescens has the same time also is 9 hours by which time the shortest generation reaches exponential time. So it can be seen that prior to exponential phase in these bacteria is an adaptation phase of bacteria and after the exponential phase is the stationary phase of bacteria. In bacteria Brevundumonas diminuta and Pseudomonas aerogirosa have more time to adapt to this case due to environmental factors such as temperature, $\mathrm{pH}$, moisture, osmotic pressure and DO (disolve Oxygen) is not in accordance with the two types of bacteria so that a phase of adaptation longer than Pseudomonas citronelis and Pseudomonas fluorescens [36].

The shortest generation time data will be used in the manufacture of starter cultures mix to mixed cultures of bacteria so that the time used to shaker in the manufacture of starter equal to the shortest generation time is generated. In the manufacture of mixed cultures of bacteria that is in a shaker by the shortest generation time, from the above data it is known that Brevundumonas diminuta and Pseudomonas aerogirosa are 12 hours, and Pseudomonas fluorescens and Pseudomonas citronelbis is 9 hours. Making the mixed culture begins with the inoculation of bacteria and Pseudomonas diminuta Brevundumonas aerogirosa, and after 3 hours was inoculated with Pseudomonas fluorescens and Pseudomonas citronelbis, resulting in 12 hours of mixed cultures of bacteria were prepared.

One of the factors that influence the formation of bio surfactant is microbial growth medium $\mathrm{pH}$ environment [37]. In this study investigated the effect of $\mathrm{pH}$ on bio surfactant production of mixed culture of bacteria such Brevundumonas diminuta, Pseudomonas fluorescens, Pseudomonas aerogirosa, Pseudomonas citronelbis, with a variation of $\mathrm{pH} 5.0$ to $\mathrm{pH} 9.0$ at which it already includes three conditions, namely $\mathrm{pH}$ acidic $\mathrm{pH}, \mathrm{pH}$ neutral and alkaline $\mathrm{pH}$. Bio surfactant analyzed based on the recovery of oil produced so that the production bio surfactant is best known. Results obtained from the oil recovery at $\mathrm{pH}$ range of 5.0 to 9.0 as following Fig. 3 .

The graph shows that the acidic $\mathrm{pH}$ bio surfactant has a recovery value is high enough, but at neutral $\mathrm{pH}$ conditions showed production higher than acidic $\mathrm{pH}$, while alkaline $\mathrm{pH}$ showed the lowest production especially $\mathrm{pH} 9$ which shows that do not produce oil recovery. This shows that at $\mathrm{pH} 7.0$ the enzymes involved in the formation of bio surfactant works better than other $\mathrm{pH}$ resulting in the highest oil recovery. In this research used crude bio surfactant (without any separation treatment from the matrix). 


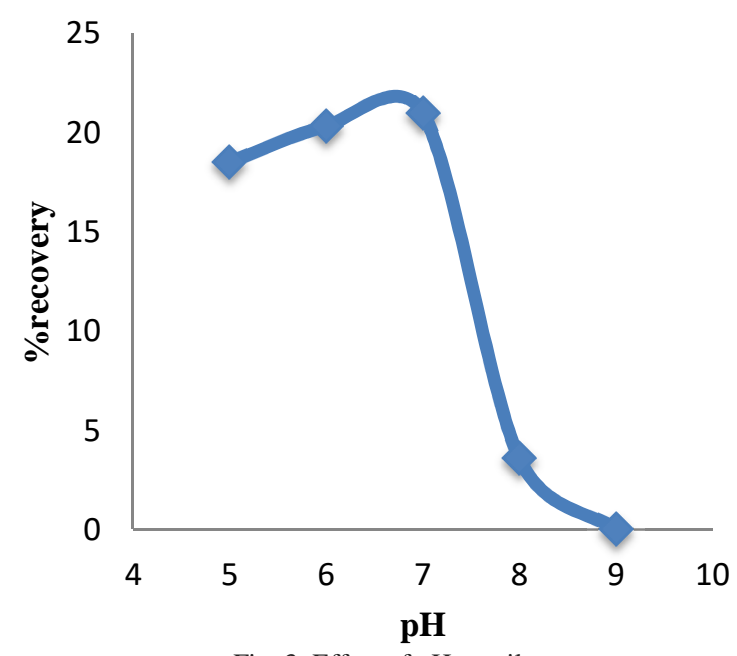

Fig. 3 Effect of $\mathrm{pH}$ on oil recovery

In previous studies, the maximum bacterial growth $\mathrm{pH}$ to obtain the number of bacterial cells in mixed cultures contained at $\mathrm{pH} 7$ is the same as in recover maximum oil contained at $\mathrm{pH}$ 7. This indicates that the bio surfactant mixed culture of bacteria associated with growth, where if the growth rate is high than the rate of production increased bio surfactant [38].

Production of oil recovery at $\mathrm{pH} 9$ shows that are not produced oil recovery which is in line with previous studies that result in low populations in the consortium of bacteria on the base condition so that the bio surfactant produced is also low. The ability to produce bio surfactant in base condition is very low; this is because the microorganisms under alkaline conditions very little ability in deciphering hydrocarbons [39]. Bio surfactant properties are anionic surfactant resulted into the slow ionized water. The goat blood tests at the base conditions result diameter clear zone are very low so the smaller the reduction of surface tension and interfacial that occur around the colony and cause bio surfactant produced lower [40].

\section{A. GC Analysis of Petroleum}

GC analysis provides information on the number of components making up the petroleum before extraction and after extraction using crude bio surfactant. GC chromatogram analysis results are shown in Fig. 4.

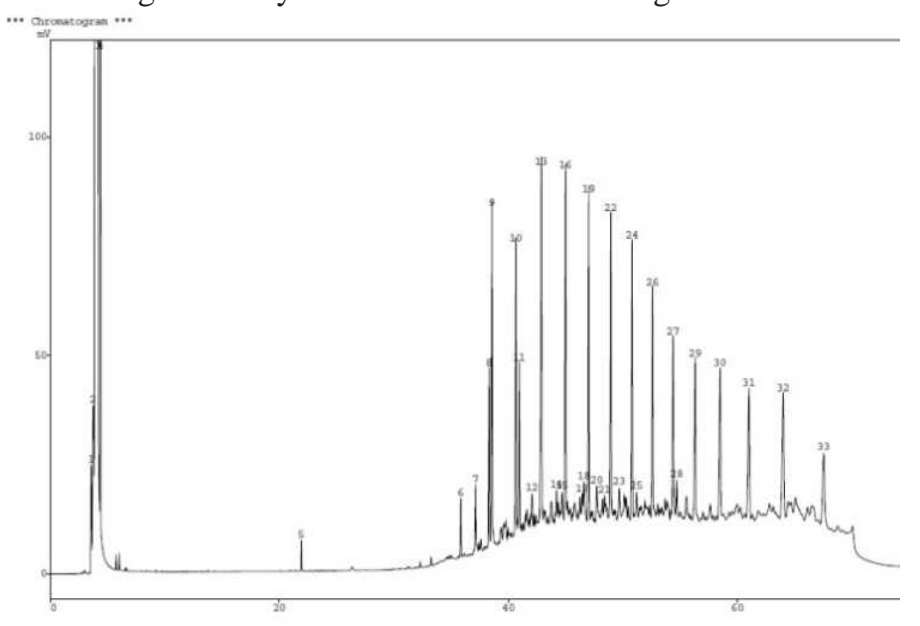

(a)

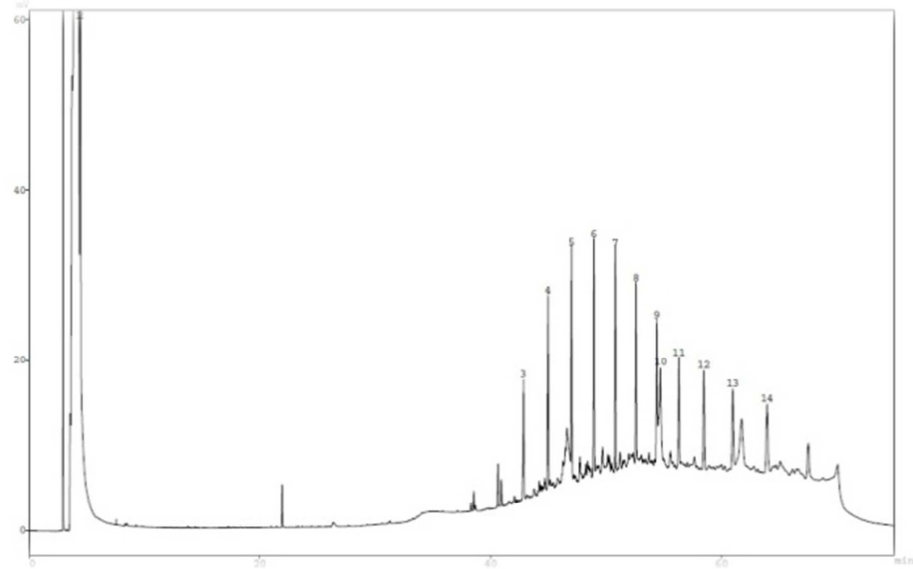

(b)

Fig. 4 The chromatograms for (a) the initial TPH prior to the addition of crude bio surfactant, (b) the final TPH after the addition of crude bio surfactant

In Fig. 2 the two chromatograms are (a) chromatogram of the initial condition of soil contained oil sample and (b) chromatogram of treated sample by using bio surfactant. There are 33 chromatogram's peaks of extract oil from soil contained oil. After the sample was treated by using bio surfactant, it shows 14 chromatogram's peaks. The discrepancy could indicate a change in the peak at the initial condition of TPH and after the addition of crude bio surfactant. Changes that occur in the chromatogram initial condition and final condition after the addition of crude bio surfactant with 19 peaks disappear, the 10 peaks are reduced peaks area, and one experienced an increase in peak area. From the data above shows that the initial and after adding more crude bio surfactant decreased chromatogram peak area. The decrease in the peak areas in the chromatogram was caused by the breakdown of hydrocarbons into simpler compounds. This is largely determined by the type of bacteria. Where in this study using a mixed culture of bacteria in the genus Pseudomonas and bio surfactant produced is Rhamnolipid. Breakdown of hydrocarbons into simpler compounds can be shown through the data histogram. Histogram data can be determined based on the identical parts of each chromatogram. The data were calculated by the difference in percent abundance before and after the addition of crude bio surfactant. Data histogram can be seen below in Fig. 5 .

Based on the histogram is shown in Fig. 5 can be seen that the data the difference in abundance mostly percent showed a negative number, which means that most petroleum hydrocarbons could be dissolved in the bio surfactant. In this study bio surfactant can dissolve the short-chain compounds at a temperature of $150^{\circ} \mathrm{C} ; 155^{\circ} \mathrm{C}$, and can dissolve longchain compounds with temperatures of $178^{\circ} \mathrm{C} ; 184^{\circ} \mathrm{C} ; 190^{\circ} \mathrm{C}$; $197^{\circ} \mathrm{C}$. This shows that bio surfactant from the mixed culture bacteria; Brevundumonas diminuta, Pseudomonas fluorescens, Pseudomonas aerogirosa, and Pseudomonas citronelbis bacteria can dissolve hydrocarbons short chain and long chain. There is also an increase in the abundance that shows the percent residue of the compound which is at a temperature of $164^{\circ} \mathrm{C} ; 169^{\circ} \mathrm{C} ; 173^{\circ} \mathrm{C} ; 174^{\circ} \mathrm{C}$ which showed the addition of peaks in the chromatogram. The fraction of 
carbon chains contained in the chromatogram can be identified based on the methodology used temperature program [41]. The fraction of the carbon chain can be grouped based on the temperature range of programs such as the following:

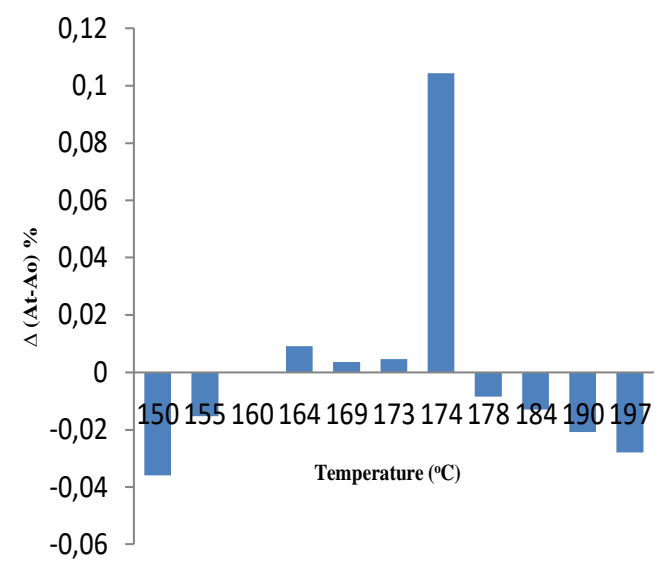

Fig. 5 Histogram of dissolved hydrocarbons between the initial TPH chromatogram and chromatogram after the addition of crude bio surfactant of mixed cultures

TABLE II

THE TEMPERATURE RANGE OF HYDROCARBON COMPOUNDS IN THE GC ANALYSIS

\begin{tabular}{|c|c|}
\hline Temperature range & $\begin{array}{l}\text { The fraction of carbon } \\
\text { chains identified }\end{array}$ \\
\hline$<100^{0} \mathrm{C}$ & $<\mathrm{C}_{10}$ \\
\hline $100-150^{0} \mathrm{C}$ & $\mathrm{C}_{11}-\mathrm{C}_{14}$ \\
\hline $150-200^{\circ} \mathrm{C}$ & $\mathrm{C}_{15}-\mathrm{C}_{17}$ \\
\hline $200-250^{0} \mathrm{C}$ & $\mathrm{C}_{18}-\mathrm{C}_{21}$ \\
\hline $250-300^{0} \mathrm{C}$ & $>\mathrm{C}_{22}$ \\
\hline
\end{tabular}

Based on Table 2, the data histogram can be identified fraction of the carbon chain, where the short-chain $\mathrm{C}$ dissolved at the temperature fractions $150 ; 155 ; 178^{\circ} \mathrm{C}$, and are also soluble in carbon length chain at temperature fractions $184 ; 190 ; 197^{\circ} \mathrm{C}$ included in the fraction of carbon chain $\mathrm{C}_{15}-\mathrm{C}_{17}$.

\section{CONCLUSION}

Based on data growth and development of the mixed culture of bacteria, i.e.,: Brevundumonas diminuta, Pseudomonas fluorescens, Pseudomonas aerogirosa, and Pseudomonas citronelbis, it is seen that the bacteria over the maximum amount in the condition of a neutral $(\mathrm{pH} 7)$ by the number of bacteria ranged 2.14.x $10^{7} \mathrm{CFU} / \mathrm{mL}$, this amount is more than the number of bacteria in the acid environment that is $1.51 \times 10^{7} \mathrm{CFU} / \mathrm{mL}$ and a base which ranges 1.23 x. $10^{7} \mathrm{CFU} / \mathrm{mL}$

The effect of $\mathrm{pH}$ on the recovery of oil in producing bio surfactant the most effective recovery percentages contained in a neutral atmosphere environmental conditions $(\mathrm{pH} 7)$ that is equal to $20.97 \%$, this percentage more than the percentage recovery acidic condition in the amount of 18.51 and bases condition $3.60 \%$.

The results of GC data showed that the compound is lost resulting in decrease in the number of compounds from 33 in the chromatogram prior to the addition of crude bio surfactant to 14 on the chromatogram after the addition of crude bio surfactant, this is because the hydrocarbons in bio surfactant which can dissolve the oil in a short carbon chain fraction at temperatures of $150^{\circ} \mathrm{C} ; 155^{\circ} \mathrm{C} ; 178^{\circ} \mathrm{C}$ with delta percentage abundance $-3.60 \% ;-154 \% ;-0,85 \%$, and also dissolves the fraction of long carbon chains at temperatures fraction of $184 ; 190 ; 197^{\circ} \mathrm{C}$ with delta percentage abundance $-1.30 \% ;-2.09 \% ;-2.79 \%$ which is included in the fraction of carbon chain $\mathrm{C} 15-\mathrm{C} 17$

MEOR represents a truly eco-friendly petroleum recovery process employing biotechnological resources and techniques that can be used to replace and augment the traditional EOR processes and flooding chemicals.

\section{REFERENCES}

[1] G. Dehghan-Noudeh, B.S. Fazly Bazaz and M.R. Housaindokht "Comparative study of the hemolytic and Surface activities of the bio surfactant produced by Bacillus subtilis ATCC6633 With some synthetic surfactants". IJBMS., 2003, vol 6, pp 1-8.

[2] G.Dehghan-Noudeh, M.H. Moshafi, E. Behravan, S. Torkzadeh and M.A. Afzadi. "Screening three strains of Pseudomonas aeruginosa: Prediction of biosurfactant-producer strain". Am. J. Applied Sci. 2009, vol 6: pp 1453-1457. DOI: 10.3844/ajassp.2009.1453.1457

[3] C. Chayabutra, J. Wu and L.K. Ju, "Rhamnolipid production by Pseudomonas aeruginosa under denitrification: Effects of limiting nutrients and carbon substrates". Biotechnol. Bioeng. 2001, vol 72 pp 25-33. PMID: 11084590

[4] N.N .Volchenko, , S.G. Karasev, D.V. Nimchenko and E.V. Karaseva. "Cell hydrophobicity as a criterion of selection of bacterial producers of biosurfactants. Microbiology". 2007, vol 76 pp 112-114. DOI:10.1134/ S0026261707010158

[5] S.Y. Chen, Y.H Wei and J.S Chnd.'Repeated pH-stat fed-batch fermentation for rhamnolipid production with indigenous Pseudomonas aeruginosa S2". Applied Microbial. Biotechnol.. 2007, vol 76 pp 67-74. DOI: 10.1007/ s00253 -007-0980-2

[6] J.C. Mata-Sandoval, J. Karns and A. Torrents. "High-performance liquid chromatography method for the characterization of rhamnolipid mixtures produced by pseudomonas aeruginosa UG2 on corn oil". J. Chromatogr. A. 1999 vol 864 pp 211-220. PMID:10669288

[7] R.M. Maier, and G. Soberon-Chavez."Pseudomonas aeruginosa rhamnolipids: Biosynthesis and potential applications. Applied Microbiol. Biotechnol". 2000 vol 54 pp 625-633. DOI:10.1007/s002530000443

[8] M. Deleu, and M. Paquot.'From renewable vegetables resources to microorganisms: New trends in surfactants". Comptes Rendus Chimie. 2004 vol 7 pp 641-646. DOI: 10.1016/j.crci.2004.04.002

[9] R.S. Makkar, and S.S. Cameotra. An update on the use of unconventional substrates for biosurfactant production and their new applications. Applied Microbiol. Biotechnol. 2002 vol 58 pp 428434. PMID: 11954787

[10] C.G. Ginkel. "Complete degradation of xenobiotic surfactants by consortia of aerobic microorganism". Biodegradation. 1996 vol 7 pp 151-164. DOI: 10.1007/BF00114627

[11] P.S. Babu, , A.N. Vaidya, A.S. Bai, R. Kapur and A. Juwarkar."Kinetics of biosurfactant production by Pseudomonas aeruginosa strain BS2 from industrial wastes", Biotechol. Lett. 1996 vol 18 pp 263-268.DOI:10.1007/ BF00142942

[12] M.I.V. Dyke, S.L. Gulley, H. Lee and J.T. Trevors. "Evaluation of microbial surfactants for recovery of hydrophobic pollutants from soil", J. Indus. Microbol. Biotechnol. 1993 vol 11 pp 163-170. DOI:10.1007/BF01583718

[13] S. Sonawdekar, "Bioremediation: A boon to hydrocarbon degradation", International Journal of Environmental Sciences. 2012, vol. 2, pp. 2408-2423.

[14] I.N.E. Onwurah, V. N. Ogugua, N. B. Onyike, A. E. Ochnogor, and O. F. Otitoju, "Crude oil spills in the environmental, effects and some innovative clean-up biotechnologies", International Journal of Environmental Sciences. 2007, vol 1 pp 307-320. 
[15] L. Haider, M.T. Fischer, J.M. Frischer, J. Bauer and R. Hoftberger.. Oxidative damage in multiple sclerosis lesions. Brain 2011 vol 134 pp 1914-1924. DOI:10.1093/ brain/awr128

[16] A. Dadrasina and S. Ismail, "Bio-enrichment of waste crude oil polluted soil: Amended with Bacillus 139SI and organic waste," International Journal of Environmental Science and Development. 2015, Vol. 6, No. 4, pp 241-245

[17] A. Nugroho. "Produksi Gas Hasil Biodegradasi Minyak Bumi: Kajian Awal Aplikasinya dalam Microbial Enhanced Oil Recovery (MEOR)". MAKARA, SAINS. 2009, vol 13 pp 111-116.

[18] LMB Andaly, DA Indriani, \& N Juli. "Studi laboratorium microbial enhanced oil recovery (MEOR): efek kultur campuran bakteri penghasil biosurfaktan terhadap penurunan tegangan antar muka", Jurnal Teknologi Minyak dan Gas Bumi. 2011 vol 2 (1) pp 14-22.

[19] JD Desai, IM Banat."Microbial production of surfactants and their commercial potential", microbiology and molecular biology reviews. 1997 vol 6(1) pp 47-64.

[20] L.D Benefield, \& C.W. Randall.”Biological Process Design for Wastewater Treatment". New York : Prentice Hall Inc.1980.

[21] B Yudono, P.E. Sri, dan Munawar. Isolasi, "Karakterisasi, dan Uji Potensi Bakteri Penghasil Biosurfaktan Termotolerant dari Sumur Tua (Abandon well) di Babat Toman Musi Banyuasin Sumatera Selatan”. Inderalaya : Fakultas MIPA, Universitas Sriwijaya. 2013.

[22] K.S. Rahman, T. Rahman, P Lakshmana and I.M. Banat,"Occurrence of crude oil degrading bacteria in gasoline and diesel station soils". J. Basic Microbial., 2002, vol 42 pp 284-291. PMID: 12210553

[23] I Rasooli, S.D.A. Astaneh, H. Borna and K.A. Barchini.”A thermostable a-amylase producing natural variant of Bacillus spp. Isolated from soil in Iran". Am. J. Agric. Biol. Sci., 2008 vol 3 pp 591-596. DOI:10.3844/ajabssp.2008.591.596.

[24] M. Robert, , M.E. Mercade, M.P. Bosch, J.L. Parra and M.J. Espuny."Effect of the carbon source on biosurfactant production by psuedomonas aeruginosa 44T1", Biotech. Lett. 1989, vol 11 pp 871874. DOI:10.1007/ BF01026843.

[25] K.S.M. Rahman, T.J. Rahman, S. McClean, R. Marchant and I.M. Banat."Rhamnolipid biosurfactant production by strains of pseudomonas aeruginosa using low-cost raw materials", Biotechnol. Prog. 2002 vol 18 pp 1277-1281. DOI:10.1021/bp020071x 6

[26] C.D. Cunha, , M.D. Rosario, A.S. Rosado and S.G.F.Leite. "Serratia sp. SVGG16: A promising biosurfactant producer isolated from tropical soilduring growth with ethanol-blended gasoline". Process Biochem., 2004 vol 39 pp 2277-2282. DOI:10.1016/j.procbio.2003.11.027.

[27] F.C. Bicca, , L.C. Fleck and M.A.Z. Ayub.”Production of biosurfactant by hydrocarbon degrading Rhodococcus ruber and Rhodococcus erythropolis". Rev. Microbiol., 1999, vol 30 pp 231236. DOI:10.1590/S0001- 37141999000300008.

[28] K.S.M. Rahman, T.J. Rahman, P.Lakshmana, R. Marchant and I.M. Banat. The potential of bacterial isolates for emulsification with a range of hydrocarbons. Acta Biotechnol., 2003 vol 23 pp 335-345. DOI:10.1002/abio.200390043.
[29] N. Gofar. "Applications rhizosphere bacterial isolates hydrocarbonoclastic origin mangrove petroleum contaminated soil". Suboptimal Land Journal, 2012 vol 1 (2) pp 123-129.

[30] R.E. Buchanan \& N.E. Gibbons (CoE). “Bergey's Manual of Determinative Bacteriology”. $8^{\text {th }}$ Ed. S.T. Cowan, J.G. Holt, J. Liston, R.G.E. Murray, C.F. Niven, A.W. Ravin \& R.Y. Stanier (Eds.). 1974. Baltimore.

[31] Munawar." Study Statistics Against Organic Nutrients and Inorganic Tests for In Situ Bioremediation of Oil Spill Earth with biostimulation method in Coastal Environments". J. Scientific Environmental Engineering. 1999 vol 2 pp 41-54.

[32] M.J. Pelczar, E.C.S. Chan. "Fundamentals of Microbiology" I. Hadioetomo RS. Imas T, Tjitrosomo S, SL digits, translator; Jakarta: Indonesia University Press. Translation from: "Elements of Microbiology". 1986. Volume 1.

[33] Refdinal.'Effect of $\mathrm{pH}$ and Temperature on the Establishment of biosurfactants by the bacterium Pseudomonas aeruginosa". Proceedings of the National Seminar on Chemistry, 2014. ISBN: 978-602-0951-00-3.

[34] N Kosaric."Biosurfactants and TheirApplications for Soil Bioremediation". Food Technol. Biotechnol. 2001 vol 39(4) pp 295304.

[35] D. Lukito." Growth of Pseudomonas aeruginosa and decolorization Compound Color Red and Orange Yellow Strawberry in Bulk Conditions". Scientific Journal. 2013 vol.2. No.1 Surabaya University Students.

[36] WG Litaay. "The ability of Pseudomonas aeruginosa in. Lowering the phosphate content of wastewater Hospital. Essay. (Published) 2013. Yogyakarta: ATMA Jaya Yogyakarta University.

[37] A. Khopade, R. Biao, X. Liu, K. Mahadik, L. Zhang and C. Kokare."Production and stability studies of the biosurfactant isolated from marine Nocardiopsis sp. B4". Desalination, 2012 vol 285 pp 198-204.

[38] P. Suryatmana, Edwan K, Enny R dan Wisjnuprapto. "Optimasi Produksi Inokulan dan Ko-inokulasi Azotobacter chrococcum dalam Upaya meningkatkan Kinerja Bioremediasi Tanah yang Tercemar Limbah Minyak Bumi”. Laporan akhir dan Seminar Evaluasi RUT XI. 2004. Kementrian Riset dan Teknologi RI. Serpong.

[39] R.E. Laini, Exploration of the bacteria as a potential oil well MEOR agent (Microbial Enhanced Oil Recovery). 2014. Thesis, Palembang: Sriwijaya University of Natural Sciences-Biology.

[40] B.S. Manurung, Potential Test and synergism Petrofilik Producing Bacteria biosurfactants from Old Wells (Abandon Well) for MEOR Technology Development (Microbial Enhanced Oil Recovery). 2014Essay. Inderalaya: Depart. Of Biology FMIPA-Sriwijaya University.

[41] B. Yudono. An Investigation into the premature cracking asphaltic pavement in hot arid climate. 1994, Thesis School of Chemistry, University of Bristol. 